\title{
Nutrient Composition of Dehydrated Drumstick Leaves (Moringa oleifera) Powder
}

\author{
J. Deepa*, Deepika R. Kattimani and N. V. Muruli \\ Department of Food Science and Nutrition, University of Agriculture Science, \\ Bengaluru, India \\ *Corresponding author
}

\section{A B S T R A C T}

\section{Keywords}

Composition,

Leaves powder,

Nutrient, Drumstick

leaves

Article Info

Accepted:

20 January 2021

Available Online:

10 February 2021
One of the vital objectives of this study is to analyze the nutrient composition of drumstick leaves powder and to create awareness for popularization of products based on drumstick leaves in daily diet. Data were analysed using one-way Analysis of Variance (ANOVA) procedure. Drumstick leaves powder has moisture content about 5.53 percent. Corresponding carbohydrates and energy content of drumstick leaves powder were $45.65 \mathrm{~g}$ and $310 \mathrm{Kcal} / 100 \mathrm{~g}$ respectively. Protein and fat content were $22.40 \mathrm{~g} / 100$ and $4.30 \mathrm{~g} / 100 \mathrm{~g}$ respectively. Crude fibre content of drumstick leaves was $13.23 \mathrm{~g} / 100 \mathrm{~g}$. The vitamins such as beta-carotene and vitamin - c content of drumstick leaves powder was $32570.67 \mu \mathrm{g}$ and $100.53 \mathrm{mg} / 100 \mathrm{~g}$ respectively. The minerals such as iron and calcium were found to be $24.33 \mathrm{mg}$ and $632.32 \mathrm{mg}$ per $100 \mathrm{~g}$ respectively. The dehydrated drumstick leaves powder got good acceptability and having fairly good storage stability which can be promoted as a green leafy vegetable for preparation of souring chutney, sauces and curries in regular consumption.

\section{Introduction}

The green leafy vegetables are always considered as an excellent component of the habitual diet in the tropical and also in temperate countries. They are protective foods and also highly beneficial for the maintenance of health and prevention of diseases. The diverse agro climatic condition of India ensures availability of different varieties of fresh fruits and vegetables. The production of fruits and vegetables in world, India stands second next to china. India produced 162.19 million metric tonnes of vegetables with cultivated area of 9.21 million hectares as per National Horticulture database published by National Horticulture Board of India, during 2012-2013. Green leafy vegetables are perishable in nature (Kakade and Neeha, 2014). According to the report of 2016 
vegetables are grown over 9.5 million hectare with the production of 168.30 million tonnes (Mazumder et al., 2016).

Moringa oleifera an aboriginal of India subcontinent is a member of the Moringaceae family of perennial angiosperm plants, which includes 13 other species (Farooq et al., 2012). The plant is grown best in dry sandy or loamy soil that is slightly Alkaline (Abdul, 2007 and Asante et al., 2014).

Although it is adaptable to various soil conditions from varying $\mathrm{PH}$ of 4.5 to 8.0 . It is not able to tolerate water logging, freezing or frosts conditions (Asante et al., 2014 and Radovich, 2011). Leafy vegetables occupy an important position in the India diet. India produce about $12 \%$ of the total world's production of vegetables but it is not enough to meet this country's requirement (Singh et al., 2003).

Moringa oleifera is a fast growing, deciduous tree. It can reach a height of 10-12 m (32-40 $\mathrm{ft})$ and can also reach a diameter of $45 \mathrm{~cm}(1.5$ $\mathrm{ft})$. The bark has a whitish-gray color and is surrounded by a dense cork.

The young shoots have a purple or greenishwhite, hairy bark. The tree has an open crown of drooping, fragile branches, and the leaves form feathery leaves of tripinnate leaves (Anwar et al., 2007). The flowers are bisexual and fragrant, united by five unequal, thinly veined, yellowish- white petals. The flowers are about $1.0-1.5 \mathrm{~cm}(1 / 2 ")$ long and $2.0 \mathrm{~cm}$ (3/4") broad.

They grow on slender, hairy stalks in spreading or drooping later flower clusters which have a length of $10-25 \mathrm{~cm}$. The flowers are fragrant and bisexual, surrounded by five unequal, thinly veined, yellowish white petals. The flowers are about $1.0-1.5 \mathrm{~cm}$ (1/2") long and $2.0 \mathrm{~cm}(3 / 4 ")$ broad (Singh et al., 2014). Moringa oleifera is one of the most helpful tropical trees and is generally grown at back side of the home. It is good sources of vitamins and minerals. It is significant source of $\mathrm{B}$ vitamins, vitamin $\mathrm{C}$, provitamin $\mathrm{A}$ as beta carotene, vitamin $\mathrm{K}$, dietary fiber, protein, potassium, manganese and magnesium and also rich source of many bioactive compounds viz. terpenoids, alkaloids, $\mathrm{p}-$ cymene, eugenol, chavicol, flavonoids, saponins, allyl catechol, cadinenecarvacrol, estragol, caryophyllene, chavibetol, cineole etc.

It is recognized for its food and nutritional value, with forage, medicinal, and seasoning properties, being used in culinary, fuel, and cosmetics industries and in water treatment for human consumption (Singh et al., 2014).

\section{Materials and Methods}

\section{Collection of drumstick leaves}

Medium mature leaves of drumstick were collected from a fully grown tree in University of Agricultural Sciences, GKVK campus, Bengaluru, Karnataka, India for the study. The leaves were initially separated from the stalks and other extraneous matter was cleaned with brine and under running water.

\section{Drying method: Oven drying}

The oven was preheated to $60^{\circ} \mathrm{C}$ and then the single layer loaded trays were kept. The temperature was maintained at $60^{\circ} \mathrm{C}$ and the process was carried out for 6 hours.

\section{Analysis Nutrients of the Sample}

The Nutrient composition of the drumstick leaves powder was analyzed for macro and micro nutrients such as moisture, carbohydrates, energy, protein, fat, crude fiber, $\beta$-carotene, vitamin $\mathrm{C}$, iron and calcium using standard methods (AOAC, 1980). 


\section{Moisture content estimation of the sample}

Moisture content was determined by taking 10 $\mathrm{g}$ of sample in petridish and followed by drying carried out in a hot air oven at $60^{\circ} \mathrm{C}$ temperature, then cooled and weighed sample.

Moisture per cent $=$

Fresh sample $(\mathrm{g})$ - Dry sample $(\mathrm{g}) \times 100$

Fresh sample (g)

\section{Protein content estimation of the sample}

Protein content of the dried tender drumstick leaves sample was calculated as percent total nitrogen by the Kjeldhal method.

Protein $(g / 100 g)=$

Titre value $\times$ Normality of HCL $\times 14.001 \times 6.25 \times 100$

Sample weight $(\mathrm{g}) \times 1000$

\section{Fat content estimation of the sample}

Fat content was determined as crude ether extract by using sample which is basically moisture free. For the removal of solvent evaporation process was adopted and the weighing was carried out for residue of the fat.

Fat content $(\mathrm{g} / 100 \mathrm{~g})=$

Weight of the ether extract $\times 100$

Weight of the sample taken

Crude fiber content estimation of the sample

The estimation of crude fiber was carried out by using moisture and fat free samples and expressed as $\mathrm{g} / 100 \mathrm{~g}$ of sample.

Crude fibre $(\mathrm{g} / 100 \mathrm{~g}$ sample $)=$ [100-(moisture+fat) $] \times(\mathrm{We}-\mathrm{Wa})$

Wt. of sample taken (moisture and fat free)
Vitamin C content estimation of the sample

Ascorbic acid content was determined calorimetrically. Ascorbic acid was first dehydrogenated by bromination. The dehydroascorbic acid was then reacted with 2 , 4 dinitrophenyl hydrazine to form osazone and dissolved in sulphuric acid to give an orangered color solution which was measured at 540 nano meter.

Beta-carotene content estimation of the sample

The beta-carotene analysis was done by following procedure 5 to $10 \mathrm{~g}$ of sample was taken and acetone about $25 \mathrm{ml}$ was added into it, then the mixture was transferred to an empty beaker grinding was done and allowed to stand for few minutes then filtration was carried out.

The residue was subjected to decanting and later it was subjected to acetone extraction process. Then $100 \mathrm{ml}$ of $5 \% \mathrm{Na}_{2} \mathrm{SO}_{4}$ solution and petroleum ether about 15 mililiter were added to extract.

Then along with petroleum ether volume was made up to the quantity of $50 \mathrm{ml}$ and $452 \mathrm{~nm}$ absorbance was used to measure beta carotene content.

\section{Ash content estimation of the sample}

5 grams of sample was taken in crucible. Then the charring carried out slowly in a muffle furnace for about 240 to $300 \mathrm{~min}$ at $6000 \mathrm{C}$ temperature. Later the sample was taken out cooled and weighing has done to know the ash content of the sample.

Ash content (g/100g sample)

$=$ Weight of the ash $\times 100$

Weight of the sample 
Table.1 The nutrient content of drumstick leaves powder/100g.

\begin{tabular}{|c|c|}
\hline Nutrients & Content per $100 \mathrm{~g}$ \\
\hline Moisture (\%) & 5.53 \\
\hline Protein (g) & 22.40 \\
\hline Fat (g) & 4.30 \\
\hline Crude fiber (g) & 13.23 \\
\hline Carbohydrates (g) & 45.65 \\
\hline Energy (K cal) & 310.00 \\
\hline Ash (g) & 8.89 \\
\hline Iron (mg) & 24.33 \\
\hline Beta- carotene $(\mu \mathrm{g})$ & 32570.67 \\
\hline Calcium (mg) & 632.32 \\
\hline Vitamin- C (mg) & 100.53 \\
\hline
\end{tabular}

Fig.1 Nutrient composition of the drumstick leaves powder/100g.

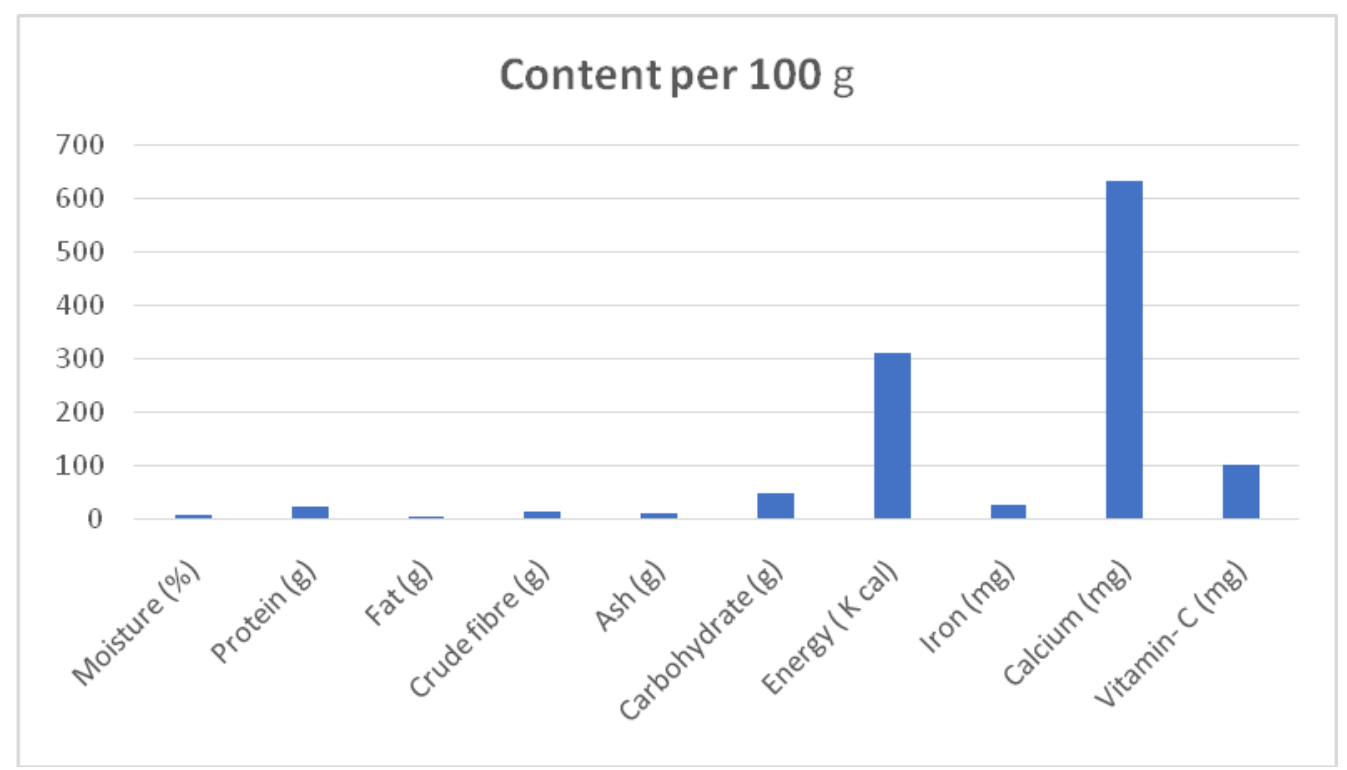

Preparation of mineral solution

Ash obtained from muffle furnace and dilute hydrochloric acid dissolved together to obtain mineral solution.

\section{Calcium content estimation of the sample}

Calcium oxalate and the solution of oxalate in dilute acid against standard potassium permanganate precipitation were done to estimate the calcium content of the sample.
Iron content estimation of the sample

Atomic absorption spectrophotometer was used to determine the Iron content of the sample and results were expressed in $\mathrm{mg} / 100$ $\mathrm{g}$ of sample.

\section{Composition of carbohydrates}

Differential method was adopted to calculate Carbohydrates content of the sample. 
$\mathrm{CHO}(\mathrm{g} / 100 \mathrm{~g})=100-[$ Protein $(\mathrm{g})+$ Fat $(\mathrm{g})$ + Ash $(\mathrm{g})+$ Fibre $(\mathrm{g})+$ Moisture $(\%)]$

\section{Composition of energy}

The composition of energy was computed for all the samples. Energy $(\mathrm{Kcal})=$ Protein $(\mathrm{g}) \times$ $4+$ Fat $(\mathrm{g}) \times 9+$ Carbohydrate $(\mathrm{g}) \times 4$

\section{Results and Discussion}

The present study was undertaken to know the nutrient composition of the drumstick leaves powder.

\section{Nutrient analysis}

The nutrient content of drumstick leaves powder such as moisture, protein, fat, crude fiber, carbohydrates, energy, ash, iron, betacarotene, calcium and vitamin $\mathrm{C}$.

Table 1 revealed that the nutrient content of drumstick leaves powder. The leaves powder contains 5.53 per cent of moisture, $22.40 \mathrm{~g}$ of Protein, $4.30 \mathrm{~g}$ of fat, $13.23 \mathrm{~g}$ of crude fibre, $45.65 \mathrm{~g}$ of carbohydrate, $310 \mathrm{Kcal}$ of energy, $8.89 \mathrm{~g}$ of ash/100 g. Vitamins like betacarotene and vitamin - c content was 32570.67 $\mu \mathrm{g}$ and $100.23 \mathrm{mg} / 100 \mathrm{~g}$ respectively. The nutrients are more in dehydrated drumstick leaves powder this may be due to the concentrated nutrient accumulated due to the loss of moisture. The study is on par with the Satwase et al., (2010) and Aremu and akintola (2014).

Figure 1 represents the nutrient composition of the drumstick leaves powder. It's showed that the dehydrated drumstick leaves powder is high in energy ( $310 \mathrm{~K} \mathrm{cal})$, calcium (632.32 $\mathrm{mg})$ and vitamin $-\mathrm{c}(100.53 \mathrm{mg})$. It has been observed that the moisture content in drumstick leaves powder was 5.53 per cent. Drumstick leaves contains protein about 22.40 $\mathrm{g}, 4.30 \mathrm{~g}$ of fat per $100 \mathrm{~g}$ was found in drumstick leaves powder. Drumstick leaves powder contains crude fibre about $13.23 \mathrm{~g}$, drumstick leaves powder has carbohydrates about $45.65 \mathrm{~g}$ and energy content was about $310 \mathrm{Kcal} / 100 \mathrm{~g}$. Ash content of the leaves powder was $8.89 \mathrm{~g}$, vitamin $\mathrm{C}$ and betacarotene content in drumstick leaves powder had $100.53 \mathrm{mg}$ per $100 \mathrm{~g}$ and $32570.67 \mu \mathrm{g}$ respectively. The minerals such as iron and calcium were found to be $24.33 \mathrm{mg}$ and $632.32 \mathrm{mg}$ per $100 \mathrm{~g}$ respectively.

The above study revealed that drumstick leaves contained appreciable quantity of nutrients and drumstick leaves being edible it can be used as green leafy vegetable for souring curries, sauces and chutneys.

\section{References}

Abdul, D.A.S., 2007, Economic importance of Moringa oleifera in Tafa local government area of Niger State.NDE Project. Federal College of Forestry Mechanization, Kaduna, Nigeria: 34.

Anwar, F., Latif, S., Ashraf, M. and Gilani, A.H., 2007.Moringa oleifera: a food plant with multiple medicinal uses. Phytotherapy Research: An International Journal Devoted to Pharmacological and Toxicological Evaluation of Natural Product Derivatives. 21(1): 17-25.

AOAC, 1980, Official Methods of Analysis, 13th edition. Association of Official Agricultural Chemists, Washington, D.C.

Aremu, A. K. and Akintola, A., 2014, Effects of some Drying Methods on nutritional Characteristics of Moringa (Moringa oleifera) Seeds. IPCBEE.75 (12): 6672.

Asante, W.J., Nasare, I.L., Tom-Dery, D., Ochire-Boadu, K. and Kentil, K.B, 2014. Nutrient composition of 
Moringa oleifera leaves from two agro ecological zones in Ghana. African Journal of Plant Science. 8(1): 65-71.

Farooq, F., Rai, M., Tiwari, A., Khan, A. A. and Farooq, S., 2012, Medicinal properties of Moringa oleifera: An overview of promising healer. Journal of Medicinal Plants Research., 6(27): 4368-4374.

Kakade, S. B. and Neeha, V. S., 2014, Dehydration of green leafy vegetable: review. Int. J. Innov. Res. Tech., 1(8): 58- 64.

Mazumder, S., Roychowdhury, A. and Banerjee, S., 2016, An overview of betel leaf (Piper betel L.): A review. Annals of Food Sci. Tech., 17(2): 367376.
Satwase, A. N., Pandhre, G. R., Sirsat, P.G. and Wade, Y.R., 2010, Studies on Drying, Characteristic and Nutritional Composition of Drumstick Leaves by Using Sun, Shadow, Cabinet and Oven Drying Methods. IOSR Journal of Applied Chemistry., 7(9):33-39.

Singh, P., and Awasthi, P., 2003, Sensory and nutritional quality evaluation of green leafy vegetable (GLV) powder incorporated food products. Proceedings of International Food Conference., 7(9):98-112.

Singh, A., Grover, K. and Sharma, N., 2014, Nutrition evaluation of value-added products using dehydrated greens for security of haematinic nutrient. Food Sci. Res. J., 5(2): 168- 173.

\section{How to cite this article:}

Deepa, J., Deepika R. Kattimani and Muruli, N. V. 2021. Nutrient Composition of Dehydrated Drumstick Leaves (Moringa oleifera) Powder. Int.J.Curr.Microbiol.App.Sci. 10(02): 27252730. doi: https://doi.org/10.20546/ijcmas.2021.1002.301 